\title{
KSIĘGI KRONIK (1-2 KRN) W QUMRAN
}

Na obecność Ksiąg Kronik wśród zwojów odnalezionych na Pustyni Judzkiej nad Morzem Martwym wskazuje rękopis 4Q118, który być może reprezentuje jakąś formę tekstu biblijnego lub jego parafrazę, jak również aluzje czy też odniesienia znajdujące się w zwojach niebiblijnych - bezpośrednie lub pośrednie - wskazujące na związki niektórych dokumentów qumrańskich z dziełem kronikarskim. ${ }^{1}$

\section{Rękopis tekstu biblijnego Pierwszej i Drugiej Księgi Kronik (?)}

Wśród zwojów biblijnych znalezionych w Qumran tylko jeden zwój z czwartej groty, mianowicie 4Q118, prezentuje tekst bardzo bliski Księgom Kronik, ${ }^{2}$ ale trudno jednoznacznie stwierdzić, czy zawiera on tekst biblijny, czy też stanowi rodzaj parafrazy lub jest utworem paralelnym do Pierwszej i Drugiej Księgi Kronik.

Analiza paleograficzna pozostałości zwoju 4Q118 wykazała, że rękopis został zapisany pismem przejściowym między hasmonejskim a herodiańskim, które jest datowane na lata 50-25 przed Chr. Dokument 4Q118 zachował się w postaci jednego małego fragmentu,

1 Zob. J. Trebolle Barrera, Chronicles, First and Second Books of, w: L. S ch if fm a n, J.C. V a nd e r K a m (red.), Encyclopedia of the Dead Sea Scrolls, t. I, New York 2000, s. 129.

2 Tekst został opublikowany w serii Discoveries in the Judaean Desert: t e $\mathrm{n}$ ż e, 118. 4QChr, w: E. U $1 \mathrm{rich}$ i in. (red.), Qumran Cave 4, XI: Psalms to Chronicles, DJD 16, Oxford 2000, s. 295-297 (+ pl. XXXVIII); t e n ż e, Édition préliminaire de 4QChroniques, RQ 15/1992, s. 523-529; zob. także wydanie tekstu w edycji elektronicznej: Biblical Dead Sea Scrolls, Bellingham 2010, Lexham Press (Logos Bible Software). 
który zawiera pozostałości dwóch kolumn tekstu. Zachowany w formie szczątkowej tekst $\mathrm{w}$ drugiej kolumnie zasadniczo pokrywa się z 2Krn 28,27 - 29,3 z drobnymi wariantami w stosunku do Tekstu Masoreckiego. ${ }^{3}$

Warianty tekstualne przedstawiają się następująco:

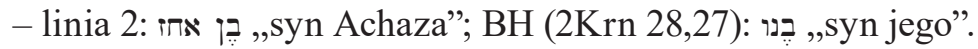

- linia 4: אֶיבה ,Ajba”; BH (2Krn 29,1): אביה ,Abijja”; najprawdopodobniej przestawienie w imieniu własnym matki króla liter ,j” oraz „,b” jest wynikiem błędu przy kopiowaniu tekstu (metateza).

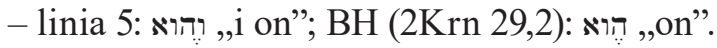

Ten tekst jest poprzedzony pozostałościami pochodzącymi z pierwszej kolumny tekstu, gdzie w trzech liniach zachowało się kilka liter oraz wyrażenie: „,i podniosłeś mnie” (יתעלני), co nie ma odpowiednika w biblijnym tekście Ksiąg Kronik (zarówno w TM, jak i w LXX). Słowo ,podniesiesz mnie” (hifil imperf. od עלה) pojawia się dwukrotnie w kontekście modlitewnym, gdzie jest mowa o działaniu Boga, który ocala (Ps 71,20; 102,25). Z tego powodu do identyfikacji rękopisu 4Q118 należy podchodzić z dużą ostrożnością, ponieważ trudno jednoznacznie stwierdzić, czy jest on rzeczywiście kopią biblijnego tekstu z Ksiąg Kronik, czy też nie. Istnieje kilka możliwości mogących wyjaśnić tę kwestię. ${ }^{4}$ Po pierwsze, 4Q118 może być wariantem tekstu Pierwszej i Drugiej Księgi Kronik, ale różnym od Tekstu Masoreckiego. ${ }^{5}$ Po drugie, być może 4Q118 stanowi kompozycję

3 Zob. M. A b e g g, Jr., P. F 1 in t, E. U 1 r i c h, The Dead Sea Scrolls Bible: The Oldest Known Bible Translated for the First Time into English, New York 1999, s. 632-633; A. Tr o n in a, Biblia w Qumran. Wprowadzenie w lekturę biblijnych rękopisów znad Morza Martwego, BZ.TNT 8, Kraków 2001, s. 33; t e n ż e, Pierwsza Księga Kronik. Wstęp, przekład z oryginału, komentarz, NKB.ST 10/1, Częstochowa 2015, s. 61; P. M u c h o w s k i, Komentarze do rękopisów znad Morza Martwego, Seria Judaica i Hebraica 1, Poznań 2005, s. 339, 385.

4 Zob. G.J. B r o o k e, The Books of Chronicles and the Scrolls from Qumran, w: R. R e z e t k o i in. (red.), Reflection and Refraction. Studies in Biblical Historiography in Honour of A. Graeme Auld, VTSup 113, Leiden-Boston 2007, s. 39.

5 Zob. M. A b e g g, Jr., P. F 1 in t, E. U 1 r i c h, The Dead Sea Scrolls Bible, s. 632 . 
będącą parafrazą biblijnego tekstu Ksiąg Kronik, w której cytuje się tekst z 2Krn 28,27 - 29,3, co wprawdzie wykluczałoby obecność biblijnego tekstu Ksiąg Kronik, ale jednocześnie wskazywałoby na autorytatywny status tych ksiąg w Qumran. ${ }^{6}$ Po trzecie, 4Q118 może być dokumentem paralelnym do obu Ksiąg Kronik, zawierającym psalmy o charakterze błagalnym, podobnie jak Parafraza Ksiag Królewskich (4Q382), gdzie znajduje się psalm błagalny podobny do modlitwy przypisywanej królowi Ezechiaszowi (Iz 38,9-20). ${ }^{7}$

Bez względu na dokładną identyfikację 4Q118 - nawet przyjmując, że ten dokument jest kopią biblijnego tekstu z Ksiąg Kronik - to jednak niezwykle intrygujący jest fakt, że księgi te są tak słabo reprezentowane wśród zwojów odnalezionych w Qumran, a w zasadzie ich brak. Powodem takiej sytuacji może być zwykły przypadek, zwój się nie zachował lub nie został odnaleziony. Niektórzy uczeni sugerują, że nikłe zainteresowanie tymi księgami wynika z tego, że tematyka obu Ksiąg Kronik skupia się wokół świątyni w Jerozolimie, od której wspólnota z Qumran się odłączyła. ${ }^{8}$ Na okoliczności związane z historią wspólnoty zwraca uwagę G.J. Brooke, który wskazuje, że 4Q118 pojawia się w Qumran dopiero w drugiej połowie I w. przed Chr., lub nawet później, ponieważ wcześniej autorytatywny charakter tych ksiąg był wprzęgnięty w polityczną propagandę władców z dynastii hasmonejskiej. Innymi słowy, dopóki Hasmoneusze sprawowali

6 Zob. J. Trebolle B arrer a, 118. 4QChr., DJD 16, s. 295.

7 Zob. A. R o fe, "No Ephod or Teraphim" - oude hierateias oude dēlōn: Hosea 3,4 in the LXX and in the Paraphrase of Chronicles and the Damascus Document, w: C. C o h e n i in. (red.), Sefer Moshe: The Moshe Weinfeld Jubilee Volume. Studies in the Bible and the Ancient Near East, Qumran, and Post-Biblical Judaism, Winona Lake 2004, s. 143; J. Tr e b o 11 e B a r r e r a, Chronicles, First and Second Books of, s. 129; zob. też A. Tr o n i n a, Pierwsza Księga Kronik. Wstep, przekład z oryginatu, komentarz, NKB.ST X/1, Częstochowa 2015, s. 61; J. N a t i, New Readings in 4Q118 I (4QChronicles) and a Parallel at 4Q381 31 (4QNon-Canonical Psalms B), RQ 29 (2017) nr 1, s. 129-138.

8 Zob. M. A b e g g, Jr., P. F 1 in t, E. U 1 r i c h, The Dead Sea Scrolls Bible, s. 632; J.C. V a n d e r K a m, P.W. F 1 in t, The Meaning of the Dead Sea Scrolls: Their Significance for Understanding the Bible, Judaism, Jesus, and Christianity, San Francisco 2002, s. 118. 
władzę, w Qumran nie było żadnej kopii Pierwszej i Drugiej Księgi Kronik czy też ich parafrazy. ${ }^{9}$

\section{Aluzje do Pierwszej i Drugiej Księgi Kronik w niebiblijnych zwojach z Qumran}

W żadnym z niebiblijnych zwojów odnalezionych w Qumran nie ma wyraźnych cytatów z Ksiąg Kronik. Można jedynie dopatrzeć się w niektórych dokumentach qumrańskich aluzji do obu tych ksiąg, czy też w szerszym znaczeniu uznać, że niektóre utwory z Qumran są związane z Księgami Kronik. ${ }^{10}$

\section{Zwój Świątyni (11QT)}

Zwój ten jest datowany na pierwszą połowę II w. przed Chr. i wykazuje związki z Księgami Kronik. ${ }^{11}$ Wydaje się, że w opisie kompleksu świątynnego, a więc budynku sanktuarium, dziedzińców,

9 Zob. G.J. B r o o k e, The Books of Chronicles and the Scrolls from Qumran, s. 40-43; t e n ż e, Between Authority and Canon: The Significance of Reworking the Bible for Understanding the Canonical Process, w: E.G. C h a z o $\mathrm{n}$ i in. (red.), Reworking the Bible: Apocryphal and Related Texts at Qumran. Proceedings of a Joint Symposium by the Orion Center for the Study of the Dead Sea Scrolls and Associated Literature and the Hebrew University Institute for Advanced Studies Research Group on Qumran, 15-17 January, 2002, STDJ 58, Leiden 2005, s. 88-89; t e $\mathrm{n} \dot{\mathrm{z}} \mathrm{e}$, Hot at Qumran, Cold in Jerusalem: A Reconsideration of Some Late Second Temple Period Attitudes to the Scriptures and their Interpretation, w: B.Y. G o ld s t e i n i in. (red.), Hā-' $\hat{s}$ h Mōshe: Studies in Scriptural Interpretation in the Dead Sea Scrolls and Related Literature in Honour of Moshe J. Bernstein, STDJ 122, Leiden-Boston 2018, s. 74-75.

10 Zob. A. L a nge, M. We i g o ld, Biblical Quotations and Allusions in Second Temple Jewish Literature, JAJSup 5, Göttingen 2011, s. 191-195; ci autorzy wyodrębniają wiele aluzji odnoszących się zarówno do obu Ksiąg Kronik, jak i do tekstów paralelnych w Księgach Samuela i Królewskich, które w tym opracowaniu pominięto; zob. też J. Tr e b o $11 \mathrm{e}$ B a r r e r a, Chronicles, First and Second Books of, s. 129; A. Tr o n in a, Pierwsza Księga Kronik, s. 62.

${ }^{11}$ Na związek Zwoju Świątyni (11QT) z Księgami Kronik wskazują, m.in. G.N. K n o p p e r s, 1 Chronicles 1-9. A New Translation with Introduction and 
różnych budowli dodatkowych i wyposażenia (kol. 3-13; 30-47), autor/ redaktor 11QT korzystał nie tylko z opisu Przybytku z czasów wędrówki przez pustynię (Wj 25-30), świątyni Salomona z 1Krl 6-7 oraz świątyni z wizji Ezechiela (Ez 40-48), ale również znał i wykorzystał materiał dotyczący świątyni z obu Ksiąg Kronik. ${ }^{12}$

Treścią Zwoju Świątyni jest opis planu architektonicznego całego kompleksu świątynnego oraz zagadnienia związane z tym tematem, przepisy odnoszące się do ofiar, świąt, czystości, a więc tego wszystkiego, co związane było z kultem świątynnym. Wszystko, co odnosi się do świątyni, jest przedstawione w 11QT jako bezpośrednio przekazane przez Boga Mojżeszowi na Synaju. W literaturze biblijnej taka tradycja jest obecna w Księdze Wyjścia i w Pierwszej Księdze Kronik, a wyraża ją przede wszystkim termin tynt (,plan”, „,model"). Ten termin odnosi się do planu świątyni niebiańskiej, według którego powinna być zbudowana świątynia/przybytek na ziemi. Według Wj 25,8-9, Bóg rozkazuje Mojżeszowi zbudować „sanktuarium (...), zgodnie z tym, co ci ukażę w odniesieniu do planu przybytku”. W 1Krn 28,11-19 stwierdza się, że „Dawid dał Salomonowi, synowi swojemu, plan [tynt]" kompleksu świątynnego, który został uprzednio dany mu od Boga (w. 11), ponieważ ,wszystko zostało mi [dane] na piśmie za pośrednictwem JHWH, abym zrozumiał plan [tynbth] wszystkich prac" (w. 19). Jak zauważył Y. Yadin, teksty opisujące plan sanktuarium, który Bóg objawił Mojżeszowi (Wj 25,1-9) oraz Dawidowi (1Krn 28,11-19), są punktem wyjścia do właściwego zrozumienia opisu całego kompleksu świątynnego w 11QT. Zestawienie opisu

Commentary, AB 12, New York 2003, s. 109; G.J. B r o o k e, The Books of Chronicles and the Scrolls from Qumran, s. 43-44.

12 Zob. D.D. S w a n s o n, The Use of Chronicles in 11QT: Aspects of a Relationship, w: D. D i m a n t, U. R a p p a p o r t (red.), The Dead Sea Scrolls: Forty Years of Research, STDJ 10, Leiden 1992, s. 290-298; t e n ż e, The Temple Scroll and the Bible: The Methodology of 11QT, STDJ 14, Leiden 1995, s. 225-226; innego zdania jest G. S t e i n s, Die Chronik als kanonisches Abschlussphänomen: Studien zur Entstehung und Theologie von 1/2 Chronik, BBB 93, Bodenheim 1995, twierdząc, że autor 2Krn 3 znał i wykorzystał materiał zbliżony do tego, który był bliski Zwojowi Świątyni. 
kompleksu świątynnego w 11QT z tekstem 1Krn 28,11-19 prowadzi do wniosku, że kompozycja Zwoju Świątyni opierała się zasadniczo na porządku poszczególnych elementów kompleksu świątyni występujących w Pierwszej Księdze Kronik, a mianowicie właściwy budynek świątyni, dziedzińce i pozostałe instalacje (ww. 11-12; por. 11QT kol. 3-7; 30-46) oraz wyposażenia świątyni (ww. 13-18; por. 11QT kol. 7-11). ${ }^{13}$ Fakt, że Bóg ukazał Mojżeszowi i Dawidowi plan/model w celu zbudowania świątyni, może świadczyć o tym, że według autora/redaktora Zwoju Światyni istnieje idealny plan świątyni oraz że może on być właściwie odczytany i zrozumiany. Dla autora 11QT architektoniczny plan świątyni przedstawiony w Zwoju Świątyni jest realizacją idealnego planu/modelu, który został dany Mojżeszowi i Dawidowi. Z tego właśnie powodu autor/redaktor omawianego zwoju korzysta z biblijnych opisów, w tym również tekstów znajdujących się w Pierwszej i Drugiej Księdze Kronik, ale nie uznaje żadnego z nich za ostateczny lub też wykonany zgodnie z poleceniem Bożym. Innymi słowy, nie traktuje żadnego z nich jako doskonałego planu kompleksu świątynnego. Opiera się na opisach biblijnych, wykorzystuje niektóre z elementów architektonicznych, które niekiedy są zbieżne, ale w ostateczności dopiero on w Zwoju Świątyni (11QT) tworzy plan/model doskonałego i ostatecznego całego kompleksu Świątynnego. ${ }^{14}$

Warto zauważyć, że oprócz tematyki związanej ze świątynią również w odniesieniu do innych zagadnień, które są bardzo wyraziste

13 Y. Y a d i n, The Temple Scroll, t. I: Introduction, Jerusalem 1983, s. 82-83, 177; zob. też D.D. S w a n s o n, The Temple Scroll and the Bible, s. 226; R.W. K $1 \mathrm{e}$ i n, 1 Chronicles: A Commentary, Hermeneia, Minneapolis 2006, s. 527; G.J. B r o o k e, The Books of Chronicles and the Scrolls from Qumran, s. 44; M. L y n c h, Monotheism and Institutions in the Book of Chronicles: Temple, Priesthood, and Kingship in Post-Exilic Perspective, FAT II, 64, Tübingen 2014, s. 118-119; E. M r o c z e k, How Not to Build a Temple: Jacob, David, and the Unbuilt Ideal in Ancient Judaism, JSJ 46/2015, s. 540.

14 Zob. L.H. S c h if f m a n, The Construction of the Temple According to the Temple Scroll, RQ 17/1996, s. 570; S.W. C r a w for d, The Temple Scroll and Related Texts, Companion to the Qumran Scrolls, Sheffield 2000, s. 34. 
w Księgach Kronik, można uznać, że miały one wpływ na pewne partie Zwoju Świątyni, m.in. podkreślanie roli i funkcji Lewitów czy też podporządkowanie króla kapłanom. ${ }^{15}$

$$
\text { Apokryf Jozuego (4Q522) }
$$

Datowany jest na połowę II w. przed Chr. i zachował się w 20 fragmentach. ${ }^{16}$ Większość $\mathrm{z}$ nich zachowała się w bardzo szczątkowym stanie, jedynie dwa zasługują na szczególną uwagę, mianowicie frag. 9 kol. 1 + frag. 10 oraz frag. 9, kol. 2. Chociaż E. Puech, jako wydawca tego tekstu w serii DJD, nie wiązał tego dokumentu z osobą Jozuego, ${ }^{17}$ to obecnie wielu uczonych uważa, że 4Q522 jest częścią Apokryfu Jozuego, a przynajmniej należy do tzw. cyklu Jozuego. ${ }^{18}$

15 Zob. G.J. B r o o ke, The Books of Chronicles and the Scrolls from Qumran, s. 44; zob. też M.M. Z a h n, The Levites, the Royal Council, and the Relationship between Chronicles and the Temple Scroll, w: J. J o k i r a n t a, M.M. Z a h n (red.), Law, Literature, and Society in Legal Texts from Qumran. Papers from the Ninth Meeting of the International Organisation for Qumran Studies, Leuven 2016, STDJ 128, Leiden 2019, s. 253-269.

16 Tekst opublikował: E. P u e c h, 522. 4QProphétie de Josué (4QapocrJosuéc?), w: te n ż e (red.), Qumran Grotte 4, XVIII: Textes Hébreux (4Q521-4Q528, 4Q576-4Q579), DJD 25, Oxford 1997, s. 39-74 (+ pl. IV-V).

17 Zob. również jego wcześniejsze publikacje: t e n ż e, Fragments du Psaume 122 dans un manuscrit hébreu de la grotte IV, RQ 9/1978, s. 547-554; t e n ż e, La Pierre de Sion et l'autel des holocaustes d'apres un manuscrit hébreu de la grotte 4 (4Q522), RB 99/1992, s. 676-696.

18 Tak uważają np. E. Q i m r o n, Concerning “Joshua Cycles” from Qumran, Tarbiz 63/1994, s. 503-508 (w języku hebrajskim, angielskie podsumowanie); E. To v, Joshua, Book of, w: L. S c h if f m a n, J.C. V a n d e r K a m (red.), Encyclopedia of the Dead Sea Scrolls, t. I, New York 2000, s. 433; E. To v, The Rewritten Book of Joshua as Found at Qumran and Masada, w: t e n ż e, Hebrew Bible, Greek Bible, and Qumran: Collected Essays, TSAJ 121, Tübingen 2008, s. 72-73; D. D i m a n t, The Apocryphon of Joshua: 4Q522 9 ii: A Reappraisal, w: S.M. P a u 1 i in. (red.), Emanuel: Studies in Hebrew Bible, Septuagint, and Dead Sea Scrolls in Honor of Emanuel Tov, VTSup 94, Leiden 2003, s. 179-182; F. García Martíne z, The Dead Sea Scrolls and the Book of Joshua, w: N. D a v i d, A. L a n g e (red.), Qumran and the Bible: Studying the Jewish and Christian Scriptures in Light of the Dead Sea 
Prawdopodobne aluzje do obu Ksiąg Kronik znajdują się w dwóch miejscach dokumentu 4Q522, mianowicie w frag. 9, kol. 1, linii 15 oraz kol. 2, liniach 4-6. ${ }^{19} \mathrm{~W}$ frag. 9, kol. 1 + frag. 10 znajduje się lista miejscowości, najprawdopodobniej tych, które zdobyli Izraelici pod wodzą Jozuego: ${ }^{20}$

\begin{tabular}{|c|c|}
\hline 1 & {$[\ldots]$} \\
\hline 2 & {$[\ldots]$ i Ain Qeber, Bet [...] } \\
\hline 3 & {$[\ldots] b q^{\prime} t$ i Bet Cippor } \\
\hline 4 & [...] uderzyli na całą dolinę Micpa \\
\hline 5 & [...] Hekalim, Ja'apur i \\
\hline 6 & [...] i Mani, Ain Kober \\
\hline 7 & [...którz]y zamieszkują Chaditę i Oszel \\
\hline 8 & [...i Ma]don, który \\
\hline 9 & {$[\ldots]$ i $[\mathrm{A}]$ szkelon } \\
\hline 10 & [...] Galil i dwa [...] Szaron \\
\hline 11 & [...w Ju]dzie: Beer Szeba [i] Bealot \\
\hline 12 & [...] Qeilah, Adullam i \\
\hline 1. & [...] Gezer, Timni, Gimzon i \\
\hline 1 & [...?]chiqqar i Qitr[on] i Efranim i Sukkot \\
\hline
\end{tabular}

Scrolls, CBET 57, Leuven 2010, s. 103; zob. szczegółową analizę w: A. F e 1 d m a n, The Rewritten Joshua Scrolls from Qumran. Texts, Translations, and Commentary, BZAW 438, Berlin-Boston 2014, s. 128-167.

19 Na obecność w 4Q522 aluzji do obu Ksiąg Kronik wskazują, m.in. G.N. K n o p p e r s, 1 Chronicles 1-9, s. 110; G.J. B r o o ke, The Books of Chronicles and the Scrolls from Qumran, s. 44-45; J. Tr e b o $11 \mathrm{e}$ B a r r e r a (Chronicles, First and Second Books of, s. 129) oraz A. Tr o n in a (Pierwsza Księga Kronik, s. 62) wskazują, że wyrażenie „skała Syjonu” (frag. 9, kol. 2, linia 4) pojawia się w kontekście podobnym do 1 Krn 21,18-22,1, ale warto zauważyć, że taki zwrot nie występuje w tradycji biblijnej, zaś autor z Qumran najprawdopodobniej nawiązuje do określenia „twierdza Syjon”, które występuje w 2Sm 5,7: „I zdobył Dawid twierdzę Syjon, to znaczy Miasto Dawida" (=1 Krn 11,5).

20 Wszystkie nazwy własne są poprzedzone hebrajskim ta/taw (nota accusativi), co może wskazywać, że oryginalnie było one poprzedzone wyrażeniem „i zdobył Jozue ..." lub jemu podobnym, zob. E. To v, The Rewritten Book of Joshua as Found at Qumran and Masada, s. 79; D. D i m a n t, The Apocryphon of Joshua: 4Q522 9 ii: A Reappraisal, s. 182. 
15

[...] Bet Choron, dolne i gór[ne]

16 [...] Gulot, górne i dolne

$17[\ldots]$ potok $[\ldots]$

18 [...]

$19[\ldots]$

Tekst zachował się w stanie bardzo fragmentarycznym. Wiele nazw miejscowości wymienionych w tym fragmencie nie występuje w tekście biblijnym, z tego wynika trudność w ich identyfikacji i lokalizacji. Jednak niektóre z nich są znane z Księgi Jozuego: Madon (Joz 11,1; 12,19), Beer Szeba (Joz 15,28), Bealot (Joz 15,24), Qeilah (Joz 15,44), Adullam (Joz 15,35), Timni (por. Joz 15,10.57: Timnah), Gezer (Joz 16,3.10), Bet Choron, dolne i górne ( Krn 7,24; zob. też Joz 16,3.5), Gulot, górne i dolne (Joz 15,19).

W linii 15 pojawiają się słowa: „Bet Choron, dolne i górne”, których frazeologia jest niemal identyczna z tą, która występuje w $1 \mathrm{Krn}$ 7,24, gdzie w kontekście genealogii potomków Efraima stwierdza się, że Szeera, córka Berii ,zbudowała Bet Choron, dolne i górne”. Warto zauważyć, że wzmianka o tej miejscowości pojawia się jeszcze w 2Krn 8,5: ,...(i odbudował) Bet Choron górne i Bet Choron dolne”, w kontekście jej odbudowy przez Salomona, ale tutaj frazeologia raczej przypomina tę, która pojawia się w opisie ziemi przydzielonej plemieniu Józefa w Joz 16: „do granicy Bet Choron dolnego” (w. 3) oraz „do Bet Choron górnego” (w. 5).

W 4Q522 frag. 9, kol. 2 + frag. 10 znajduje się mowa Jozuego dotycząca czasowego umieszczenia Namiotu Spotkania poza Jerozolimą, zdobycia w przyszłości tego miasta przez Dawida i zbudowania tam świątyni przez Salomona:

$1 \quad[\ldots]$

2 nie [przybę]dą [na Syj]on, aby ustawić tam Namiot S[potkania aż do nadejścia]

3 czasów. Bo oto, syn narodzi się Jessemu, synowi Peresa, syna $\mathrm{Ju}$ [dy. I on zdobędzie]

4 skałę Syjon i wyrzuci stamtąd wszystkich Amorytów z Jer[ozolimy, i będzie zamierzał] 
5 zbudować dom dla JHWH, Boga Izraela. Złoto i srebro, [brąz i żelazo przygotuje,]

6 cedry i cyprysy sprowadzi z Libanu, aby go zbudować. I młodszy jego syn [zbuduje go. I Sadok]

7 będzie tam sprawował służbę kapłańską, pierwszy [...]. I w nim [będzie mieć upod]obanie [i JHWH będzie błogosławić go]

8 [z siedz]iby z niebi[os. Bo] umiłowany JHWH będzie mieszkać bezpiecznie i [JHWH będzie jego obrońcą przez wszystkie]

9 dni. Z nim będzie mieszkać na zawsze. Lecz teraz Amoryci tam są, i Kananejczy[cy pośród nas]

10 mieszkają, gdyż oni doprowadzili mnie do grzechu, ponieważ nie szukałem [wy]roku [urim i tummim]

11 od ciebie i oszukali mnie. I oto, dałem ich jako sługę sł[ug dla Iz]ra[ela...]

12 A teraz, ustawmy N[amiot Spo]tkania daleko od [Amorytów i Kananejczyków. I przenieśli]

13 Eleazar [i Jozu]e N[amiot Sp]otkania z Bet[el do Szilo ...]

14 Jozue [... dow]ódca wojska [...]

$15 \quad[\ldots]$

W zachowanym tekście kol. 2 można wyodrębnić dwie części. Pierwsza (linie 1-12) zawiera mowę, w której mówca wypowiada się w pierwszej osobie, zarówno w liczbie pojedynczej (linie 10-11), jak i w liczbie mnogiej (linia 12). Kontekst wskazuje, że mówcą jest Jozue, ponieważ treść w liniach 10-11 odnosi się do zawarcia przymierza z Gibeonitami (Joz 9). Taką identyfikację potwierdza również dwukrotnie pojawiające się imię Jozuego (linie 13 i 14). W zachowanej szczątkowo drugiej części (linie 12-do końca) znajdował się zapewne opis działalności Jozuego i Eleazara. ${ }^{21}$

W 4Q522 kol. 2 zostaje wyjaśniony powód, dla którego Jerozolima nie została zdobyta przez Jozuego, a Namiot Spotkania czasowo musi

${ }^{21}$ Zob. tamże, s. 198. 
przebywać poza tym miastem. Według 4Q522, Jerozolima nie została zdobyta przez Jozuego, ponieważ zgodnie z planem Boga w przyszłości dokona tego Dawid i dopiero wtedy Namiot Spotkania zostanie przeniesiony do Jerozolimy, gdzie potem syn Dawida, Salomon, zbuduje świątynię dla Boga. W ten sposób - w formie prorockiej wizji - Jozue wyjaśnia, że zgodnie z wolą Boga to Dawid, a nie on, będzie zdobywcą Jerozolimy i fundatorem przyszłej świątyni.

Aluzja do Ksiąg Kronik pojawia się w liniach 4-6, gdzie jest mowa o przygotowaniach do budowy świątyni, które poczynił Dawid. W tekście jest mowa o zdobyciu „skały Syjonu” (linia 4), zgromadzeniu złota i srebra (linia 5) oraz sprowadzeniu cedrów i cyprysów z Libanu w celu budowy świątyni (linia 6). Słownictwo tego fragmentu jest bliskie temu, które występuje w 1Krn 22: „...przygotował Dawid (...), i drewno cedrów bez liczby, ponieważ Sydończycy i Tyryjczycy przywieźli wiele drewna cedrów Dawidowi” (ww. 3-4) oraz: „I oto w biedzie mojej przygotowałem dla Domu Pana złota sto tysięcy talentów, i srebra tysiąc tysięcy talentów, i brązu oraz żelaza bez miary, bo było tego wiele" (w. 14). Ukazując zaangażowanie Dawida $\mathrm{w}$ gromadzenie materiałów potrzebnych do budowy świątyni, autor 4Q522 jest zależny od stanowiska prezentowanego w Księgach Kronik. Podczas gdy według 1Krl 5-7 Salomon uczynił stosowne przygotowania, gromadząc różnego rodzaju materiały budowlane i zbudował świątynię, to w 1Krn 21-22 i 28-29 opisuje się zakrojone na szeroką skalę przygotowania, które podjął Dawid, aby jego syn mógł w przyszłości zbudować sanktuarium dla Boga w Jerozolimie. Działalność Dawida w tym względzie objęła następujące czynności: zbudowanie ołtarza w miejscu, gdzie w niedalekiej przyszłości zostanie zbudowana świątynia (1 Krn 21,18-22,1), zgromadzenie wielkiej ilości drewna (1Krn 22, 4-5), zebranie ogromnej ilości złota, srebra, i innych cennych materiałów (1Krn 22,14; zob. 29,2-5). Krótko mówiąc, w 4Q522 frag. 9 - podobnie jak w Pierwszej Księdze Kronik podkreśla się znaczenie postępowania Dawida i jego wkład włożony w budowę świątyni w Jerozolimie. 


\section{Peszer do Księgi Rodzaju (4Q252) 22}

Dokument ten, datowany na koniec I w. przed Chr., zachował się w postaci sześciu fragmentów. Zawiera cytaty z Księgi Rodzaju (Rdz 6-49) i komentarze do wybranych epizodów dotyczących osoby i wydarzeń z życia Abrahama.

Aluzja do Drugiej Księgi Kronik pojawia się w 4Q252 kol. 2, w sekcji poświęconej uprawie winnej latorośli przez Noego i konsekwencji wynikłych z nadużycia przez niego wina (linie 5-8; Rdz $9,20-27):^{23}$

5 (...) Gdy Noe ocknął się po swoim winie, wtedy dowiedział się, co uczynił

6 mu jego najmłodszy syn, i powiedział: Przeklęty jest Kanaan. Niech będzie sługą sług dla swoich braci! I nie

7 przeklął Chama, ale jego syna, ponieważ Bóg pobłogosławił synów Noego, i będzie On mieszkać w namiotach Sema,

8 ziemię dał Abrahamowi, umiłowanemu Jego (vacat)

Autor 4Q252, wyjaśniając powód, dla którego Noe przeklął Kanaana zamiast jego ojca Chama, stwierdza, że Bóg będzie błogosławić Sema i jego potomków. W zakończeniu tego wyjaśnienia - czego brak w materiale biblijnym - wspomina się o tym, że Bóg dał ziemię Abrahamowi, który został określony jako „umiłowany Jego”, tj. ,,przyjaciel Boga". Użyte tutaj wyrażenie waha (,umiłowany Jego" - kol. 2,

22 Wydanie tekstu: G. B r o o k e, 252. 4QCommentary on Genesis A, w: G. B r o o ke i in. (red.), Qumran Cave 4.XVII: Parabiblical Texts, Part 3, DJD 22, Oxford 1996, s. 185-207 (+ pl. XII-XIII); J.L. Tr a f t o n, Commentary on Genesis A (4Q252 $=4 Q$ CommGen $A=4 Q P$ Bless), w: J. H. C h a r l e s w o r t h i in. (red.), The Dead Sea Scrolls. Hebrew, Aramaic, and Greek Texts with English Translations, PTSDSSP, t. 6B: Pesharim, Other Commentaries, and Related Documents, Tübingen-Louisville 2002, s. 203-219.

23 Na związek 4Q252 z Drugą Księgą Kronik wskazują m.in. J. Tr e b o 11 e B a r r e r a, Chronicles, First and Second Books of, s. 129; G.N. K n o p p e r s, 1 Chronicles 1-9, s. 111; G.J. B r o o k e, The Books of Chronicles and the Scrolls from Qumran, s. 46-47; A. Tr o n i n a, Pierwsza Ksiega Kronik, s. 62. 
linia 8) podkreśla - podobnie jak w Jub 17,18, CD 3,2 - wierność Abrahama wobec przymierza przez zachowywanie Bożych przykazań. ${ }^{24}$

Wydaje się, że forma wzmianki o Abrahamie nawiązuje do 2Krn 20,7, gdzie król Jozafat, w obliczu zagrożenia spowodowanego najazdem Moabitów i Ammonitów na Judę, modli się do Boga: „Czy nie Ty, Boże nasz, wygnałeś mieszkańców tej ziemi sprzed ludu Twojego, Izraela, i dałeś ją potomstwu Abrahama, przyjaciela Twego [אהבך], na zawsze?". ${ }^{25}$ Pojawiająca się w 4Q252 kol. 2, linii 8 wzmianka o Abrahamie łączy ze sobą dwa odrębne tematy, mianowicie motyw ziemi danej Abrahamowi i jego potomkom przez Boga oraz ukazanie patriarchy jako „przyjaciela Boga” (zob. Iz 41,8; 2Krn 20,7; 4Q176 frag. 1-2, kol. 1, linia 9). ${ }^{26}$

24 Zob. M. S e g a 1, The Book of Jubilees: Rewritten Bible, Redaction, Ideology, and Theology, JSJSup 117, Leiden-Boston 2007, s. 299; M.J. B e r n s t e i n, Where Are the Patriarchs in the Literature of Qumran? w: D. D i m a n t, R.G. K r a t z (red.), Rewriting and Interpreting the Hebrew Bible: The Biblical Patriarchs in the Light of the Dead Sea Scrolls, BZAW 439, Berlin 2013, s. 55; szerzej na ten temat, zob. R.G. K r a t z, Friend of God, Brother of Sarah, and Father of Isaac: Abraham in the Hebrew Bible and in Qumran, w: D. D i m a n t, R.G. K r a t z (red.), The Dynamics of Language and Exegesis at Qumran, FAT 35, Tübingen 2009, s. 80-87.

25 Zob. G. B r o o k e, 252. 4QCommentary on Genesis A, s. 200; t e n ż e, The Thematic Content of 4Q252, JQR 85/1994, s. 43; t e n ż e, Genesis, Commentary on, w: L.H. S c h if f m a n, J.C. V a n d e r K a m, i in. (red.), Encyclopedia of the Dead Sea Scrolls, t. I, s. 300; D.K. F a 1 k, The Parabiblical Texts: Strategies for Extending the Scriptures among the Dead Sea Scrolls, Companion to the Dead Sea Scrolls 8; Library of Second Temple Studies 63, London 2007, s. 131-132; M. P o p o v i ć, Abraham and the Nations in the Dead Sea Scrolls: Exclusivism and Inclusivism in the Texts from Qumran and the Absence of a Reception History for Gen 12:3, w: M. G o o d m a n i in. (red.), Abraham, the Nations, and the Hagarites: Jewish, Christian, and Islamic Perspectives on Kinship with Abraham, Themes in Biblical Narrative 13, Leiden-Boston 2010, s. 83-84.

${ }_{26}$ Zob. G. B r o o ke, The Thematic Content of 4Q252, s. 43; M. P o p o v i ć, Abraham and the Nations in the Dead Sea Scrolls, s. 83. 
Modlitwa Manassesa (4Q381 frag. 33 i 35, linie 8-11)

Utwór o takim tytule, który znajduje się w rękopisie 4Q381 (=4QPsalmy apokryficzne B) datowanym na pierwszą połowę I w. przed Chr. i zawierającym zbiór niebiblijnych psalmów, z dużym prawdopodobieństwem nawiązuje do wzmianki o modlitwie króla Manassesa w 2Krn 33,12-13.18-19. ${ }^{27}$ Być może informacja o istnieniu pokutnej modlitwy bezbożnego króla, który się nawrócił, była powodem ,uzupełnienia” tekstu biblijnego. ${ }^{28}$

4Q381 frag. 33 i 35, linie 8-11:29

8 Modlitwa Manassesa, króla Judy, gdy uwięził go król Asyrii. [Bo]że [mój ] blisko, zbawienie moje jest przed oczami twoimi, co [

27 Tradycja o pokucie i nawróceniu Manassesa zachowała się także w greckim utworze apokryficznym noszącym tytuł Modlitwa Manassesa, u Józefa Flawiusza (Antiquitates, 10,37-46) oraz w literaturze rabinicznej.

28 Na związek Modlitwy Manassesa (4Q381 frag 33 i 35) z 2Krn 33 wskazują, m.in. E.M. S c h u 11 e r, 4Q380 and 4Q381: Non-Canonical Psalms from Qumran, w: D. D i m a n t, U. R a p p a p o r t (red.), The Dead Sea Scrolls: Forty Years of Research, s. 94-95; M.S. P a j u n e n, The Prayer of Manasseh in 4Q381 and the Account of Manasseh in 2 Chronicles 33, w: G.J. B r o o k e i in. (red.), The Scrolls and Biblical Traditions: Proceedings of the Seventh Meeting of the IOQS in Helsinki, STDJ 103, Leiden-Boston 2012, s. 143-161; A. Tr o n i n a, Pierwsza Ksiega Kronik, s. 62; J. Tr e b o 11 e B a r re r a, Chronicles, First and Second Books of, s. 129; innego zdania jest W.M. S c h n i e d e w ind (A Qumran Fragment of the Ancient "Prayer of Manasseh"? ZAW 108/1996, s. 105-107), który uważa, że modlitwa w 4Q381 jest kompozycją powstałą w okresie przedwygnaniowym i stanowiła źródło dla autora/redaktora Ksiąg Kronik.

29 Tekst opublikowany w: E.M. S c h u 11 e r, 4Q381. 4QNon-Canonical Psalms B, w: E. E s hel i in. (red.), Qumran Cave 4.VI: Poetical and Liturgical Texts, Part 1, DJD 11, Oxford 1997, s. 122-126; t a ż, Qumran Pseudepigraphic Psalms (4Q380 and 4Q381), w: J.H. C h a r le s w o r th i in. (red.), The Dead Sea Scrolls. Hebrew, Aramaic, and Greek Texts with English Translations, PTSDSSP, t. 4A: Pseudepigraphic and Non-Masoretic Psalms and Prayers, Tübingen-Louisville 1997, s. 22-23; zob. też E.M. S c h u 11 e r, Non-Canonical Psalms from Qumran: A Pseudepigraphic Collection, HSS 28, Atlanta 1986, s. 146-158. 
9 Na zbawienie oblicza twojego czekam, i ja wzdrygam się przed obliczem twoim z powodu grzechów moich, ponieważ uczyniłeś wielki[m miłosierdzie swoje,] a ja sprawiłem, że wielka jest moja wina. I od[ciąłem się

10 od radości wiecznej, i nie widzi dobra dusza moja, ponieważ [ ] poszli w niewolę, i[ o]n wyniósł mnie wysoko, ponad naród [

11 A ja nie pamiętałem o tobie [w miejs]cu św[iętości twojej,] nie służyłem [tobie...]

W tradycji deuteronomistycznej (2Krl 21,1-18), Manasses, król Judy, jest ukazany jako apostata i bezbożny władca, który wprowadził kulty bałwochwalcze. W paralelnym opisie działalności króla w Dziele Kronikarskim (2Krn 33) jest mowa o bezbożnych czynach króla (ww. 1-10), ale w dalszej narracji mówi się, że król został uprowadzony przez Asyryjczyków do Babilonu, gdzie modlił się i pokutował, a Bóg wysłuchał go, przebaczył i przywrócił mu tron w Jerozolimie (ww. 11-13), a gdy wrócił, starał się naprawić popełnione wcześniej błędy (ww. 14-17). W zakończeniu podsumowującym życie i działalność Manassesa autor Drugiej Księgi Kronik stwierdza: „A pozostałe dzieje Manassesa, i modlitwa jego do Boga jego, i słowa widzących przemawiających do niego w imię JHWH, Boga Izraela, oto są one w Dziejach królów Izraela. A modlitwa jego, i odpowiedź na nią, i każdy grzech jego, i niewierność jego, i miejsca, na których budował wyżyny, i ustawił aszery oraz posągi przed ukorzeniem swoim, oto są one zapisane w Dziejach Chozaji” (ww. 18-19).

Na wzajemne związki istniejące między Modlitwą Manassesa z Qumran (4Q381 frag. 33 i 35, linie 8-11) a tekstem w 2Krn 33 wskazują następujące zbieżności: ${ }^{30}$

- w 4Q381 utwór przypisywany Manassesowi jest określony jako תפלה (,modlitwa”) (linia 8); w 2Krn 33 ten sam rdzeń

30 Zob. t e n ż e, Non-Canonical Psalms from Qumran, s. 31-32; M.S. P a j u n e n, The Prayer of Manasseh in 4Q381 and the Account of Manasseh in 2 Chronicles 33 , s. 151-153. 
(פלל ) pojawia się trzykrotnie, mianowicie dwa razy w formie rzeczownikowej w wyrażeniu ותפלתו (,i modlitwa jego" - ww. 18 i 19) oraz w formie czasownikowej: ויתפלל ( ,i modlił się" W. 13);

- $\quad$ wzmianka o uwięzieniu Manassesa przez króla Asyrii w tekście qumrańskim (linia 8) odpowiada informacji z 2Krn 33: „I sprowadził JHWH przeciw nim dowódców wojska króla Asyrii, i pochwycili Manassesa hakami, i zakuli go w podwójny łańcuch spiżowy, i uprowadzili go do Babilonu" (w. 11);

- informacja o ukorzeniu się króla przed Bogiem (linia 9) koresponduje z tym co dwukrotnie zostało stwierdzone w $2 \mathrm{Krn}$ 33: ,... i ukorzył się bardzo przed Bogiem” (w. 12) oraz ,przed ukorzeniem swoim" (w. 19);

- $\quad$ obecne w 4Q381 słowa króla: ,....a ja sprawiłem, że wielka jest moja wina" (linia 9) przywołują na myśl wyrażenie z 2Krn 33: „,...pomnożył czynienie zła w oczach JHWH” (w. 6)”;

- wyznanie króla w tekście z Qumran: „,...a ja nie pamiętałem o tobie" (linia 11) może być grą słów nawiązującą do biblijnej etymologii imienia Manassesa ( מנשה), które znaczy ,zapomnieć” ( נשהה); zob. Rdz 41,51: ,Józef dał swojemu synowi pierworodnemu imię Manasses, bo [mówił]: Dał mi zapomnieć [ynvn] Bóg o całym moim utrapieniu i o całym domu mego ojca" (zob. też Męczeństwo Izajasza 2,1-2; t.Sanhedrin 102b);

- $\quad$ pojawiające się w tekście qumrańskim wyznanie króla: „,...nie służyłem [tobie...]" (linia 11) może nawiązywać do wzmianki o bałwochwalstwie Manassesa w 2Krn 33: ,...i ustanowił ołtarze Baalom, i wzniósł aszery; i oddawał pokłon całemu wojsku niebios, i służył im" (w. 3).

$$
* * *
$$

Powyższy przegląd obecności Pierwszej i Drugiej Księgi Kronik w zwojach odnalezionych na Pustyni Judzkiej nad Morzem Martwym wskazuje, że nie cieszyły się one zbyt dużym zainteresowaniem wśród członków społeczności qumrańskiej. Świadczy o tym 
istnienie tylko jednej kopii prezentującej tekst bardzo zbliżony do biblijnego, który jednak nie jest z nim identyczny (4Q118). Ponieważ dokument 4Q118 zachował się w stanie bardzo fragmentarycznym, nie ma pewności co do jego identyfikacji. Chociaż zdaniem niektórych można byłoby uznać go za kopię tekstu biblijnego różną od wersji masoreckiej, to jednak wydaje się bardziej uzasadnione postrzeganie tego dokumentu jako parafrazy lub tekstu paralelnego do obu Ksiąg Kronik. O nikłym zainteresowaniu Księgami Kronik w Qumran świadczy również brak wyraźnych cytatów w zwojach niebiblijnych, a nieliczne aluzje w 4Q522 i 4Q252 mają jedynie status prawdopodobnego nawiązania do tych ksiąg. Natomiast w odniesieniu do Zwoju Świątyni (11QT) oraz Modlitwy Manassesa (4Q381 frag. 33 i 35, linie 8-11) można mówić o pewnego rodzaju związkach istniejących między nimi a Księgami Kronik, ale należy zauważyć, że obie te kompozycje nie są utworami własnymi wspólnoty z Qumran.

ks. Marek PARCHEM

Słowa kluczowe: Księgi Kronik (1-2Krn); Qumran; Modlitwa Manassesa; Zwój Świątyni; 4Q118, 4Q252, 4Q522

Keywords: Book of Chronicles (1-2 Chronicles); Qumran; Prayer of Manasseh; Temple Scroll; 4Q118, 4Q252, 4Q522

\section{The Books of Chronicles at Qumran}

\section{Summary}

The review of the presence of the Books of Chronicles (1-2 Chronicles) in the Dead Sea Scrolls shows that they did not enjoy any significant interest and popularity among the members of the Qumran community. This is testified by the fact that there is only one copy which contains a text which is very similar, however not identical, to the biblical one (4Q118). As the 4Q118 document has survived in a highly fragmentary state, its identification is not certain. Although some scholars believe that it can be regarded as the copy of the biblical text which differs from the Masoretic version, it seems 
more reasonable to view this document as a paraphrase or a parallel text of 1-2 Chronicles. That the Books of Chronicles were of little interest to the Qumran dwellers is also confirmed by the lack of any direct quotations in the non-biblical documents. The sparse allusions in 4Q522 and 4Q252 need to be assessed just as a probable reference to 1-2 Chronicles. On the other hand, in the case of the Temple Scroll (11QT) and the Prayer of Manasseh (4Q381 fr. 33 and 35, lines 8-11) there are some relations between these documents and the Books of Chronicles, but it should be noted that neither of the works is the composition of the Qumran community itself.

\section{Bibliografia}

\section{Teksty}

A b e g g Jr., M., F 1 in $t$ P., U 1 r i c h E., The Dead Sea Scrolls Bible: The Oldest Known Bible Translated for the First Time into English, New York 1999.

B rooke G.J., 252. 4QCommentary on Genesis A, w: t e $\mathrm{n} \dot{\mathrm{e}} \mathrm{i}$ in. (red.), Qumran Cave 4.XVII: Parabiblical Texts, Part 3, DJD 22, Oxford 1996, s. 185-207 (+ pl. XII-XIII).

$\mathrm{P}$ u e c h E., 522. 4QProphétie de Josué (4QapocrJosuéc?), w: t e n ż e (red.), Qumran Grotte 4, XVIII: Textes Hébreux (4Q521-4Q528, 4Q576-4Q579) (DJD 25), Oxford 1997, s. 39-74 (+ pl. IV-V).

S chulle r E.M., 4Q381. 4QNon-Canonical Psalms B, w: E shel E. i in. (red.), Qumran Cave 4.VI: Poetical and Liturgical Texts, Part 1, DJD 11, Oxford 1997, s. 87-172 (+ pl. IX-XV).

Schulle r E.M., Qumran Pseudepigraphic Psalms (4Q380 and 4Q381), w: C h a rle s w or th J.H. i in. (red.), The Dead Sea Scrolls. Hebrew, Aramaic, and Greek Texts with English Translations, PTSDSSP, t. 4A: Pseudepigraphic and Non-Masoretic Psalms and Prayers, Tübingen-Louisville 1997, s. 1-39.

Trafto n J.L., Commentary on Genesis A $4 Q 252=4 Q$ CommGen $A=$ 4QPBless), w: C h a rle s w o r th J.H. i in. (red.), The Dead Sea Scrolls. Hebrew, Aramaic, and Greek Texts with English Translations, PTSDSSP, t. 6B: Pesharim, Other Commentaries, and Related Documents, Tübingen-Louisville 2002, s. 203-219.

Trebolle Barrera J., 118. 4QChr, w: U lrich E. i in. (red.), Qumran Cave 4, XI: Psalms to Chronicles, DJD 16, Oxford 2000, s. 295-297 (+ pl. XXXVIII).

Tre b olle B a rre r a J., Édition préliminaire de 4QChroniques, RQ 15/1992, s. 523-529. 


\section{Opracowania}

B e r n s t e in M.J., Where Are the Patriarchs in the Literature of Qumran? $\mathrm{w}$ : D i m a $\mathrm{t}$ D., K rat z R.G. (red.), Rewriting and Interpreting the Hebrew Bible: The Biblical Patriarchs in the Light of the Dead Sea Scrolls, BZAW 439, Berlin 2013, s. 51-76.

B r o o k e G.J., Between Authority and Canon: The Significance of Reworking the Bible for Understanding the Canonical Process, w: Ch a z o n E.G. $\mathrm{i}$ in. (red.), Reworking the Bible: Apocryphal and Related Texts at Qumran. Proceedings of a Joint Symposium by the Orion Center for the Study of the Dead Sea Scrolls and Associated Literature and the Hebrew University Institute for Advanced Studies Research Group on Qumran, 15-17 January, 2002, STDJ 58, Leiden 2005, s. 85-104.

B r o o k e G.J., Genesis, Commentary on, w: S c h i f f m a n L.H., V a n d e rK a m J.C. i in. (red.), Encyclopedia of the Dead Sea Scrolls, t. I, Oxford 2000, s. 300-302.

B ro o k e G.J., Hot at Qumran, Cold in Jerusalem: A Reconsideration of Some Late Second Temple Period Attitudes to the Scriptures and their Interpretation, w: Gold s te i n B.Y. i in. (red.), Hā-'îsh Mōshe: Studies in Scriptural Interpretation in the Dead Sea Scrolls and Related Literature in Honour of Moshe J. Bernstein, STDJ 122, Leiden-Boston 2018, s. 64-77.

B r o o k e G.J., The Books of Chronicles and the Scrolls from Qumran, w: R e z e t k o R. i in. (red.), Reflection and Refraction. Studies in Biblical Historiography in Honour of A. Graeme Auld, VTSup 113, Leiden-Boston 2007, s. 35-48.

B r o o k e G.J., The Thematic Content of 4Q252, JQR 85/1994, s. 33-59.

$\mathrm{Cr}$ aw ford S.W., The Temple Scroll and Related Texts, Companion to the Qumran Scrolls, Sheffield 2000.

D i m a n t D., The Apocryphon of Joshua: 4Q522 9 ii: A Reappraisal, w: P a u 1 S.M. i in. (red.), Emanuel: Studies in Hebrew Bible, Septuagint, and Dead Sea Scrolls in Honor of Emanuel Tov, VTSup 94, Leiden 2003, s. 179-204.

F a 1 k D.K., The Parabiblical Texts: Strategies for Extending the Scriptures among the Dead Sea Scrolls, Companion to the Dead Sea Scrolls 8, Library of Second Temple Studies 63, London 2007.

F e ld m a n A., The Rewritten Joshua Scrolls from Qumran. Texts, Translations, and Commentary, BZAW 438, Berlin-Boston 2014.

García Martíne z F., The Dead Sea Scrolls and the Book of Joshua, w: D avid N., L a nge A. (red.), Qumran and the Bible: Studying the Jewish and Christian Scriptures in Light of the Dead Sea Scrolls, CBET 57, Leuven 2010, s. 97-109. 
K n o p p e r s G.N., 1 Chronicles 1-9. A New Translation with Introduction and Commentary, AB 12, New York 2003.

K r a t z R.G., Friend of God, Brother of Sarah, and Father of Isaac: Abraham in the Hebrew Bible and in Qumran, w: D i m a n t D., K r a t z R.G. (red.), The Dynamics of Language and Exegesis at Qumran, FAT 35, Tübingen 2009, s. 80-87.

L a nge A., We ig old M., Biblical Quotations and Allusions in Second Temple Jewish Literature, JAJSup 5, Göttingen 2011.

L y $\mathrm{n} \mathrm{ch}$ M., Monotheism and Institutions in the Book of Chronicles: Temple, Priesthood, and Kingship in Post-Exilic Perspective, FAT II, 64, Tübingen 2014.

M roc ze k E., How Not to Build a Temple: Jacob, David, and the Unbuilt Ideal in Ancient Judaism, JSJ 46/2015, s. 512-546.

Mu c how s k i P., Komentarze do rękopisów znad Morza Martwego, Seria Judaica i Hebraica 1, Poznań 2005.

$\mathrm{N}$ a t i J., New Readings in 4Q118 I (4QChronicles) and a Parallel at 4Q381 31 (4QNon-Canonical Psalms B), RQ 29(2017) nr 1, s. 129-138.

$\mathrm{Paj}$ u n e $\mathrm{n}$ M.S., The Prayer of Manasseh in $4 Q 381$ and the Account of Manasseh in 2 Chronicles 33, w: B ro o k e G.J. i in. (red.), The Scrolls and Biblical Traditions: Proceedings of the Seventh Meeting of the IOQS in Helsinki, STDJ 103, Leiden-Boston 2012, s. 143-161.

P o p o v i ć M., Abraham and the Nations in the Dead Sea Scrolls: Exclusivism and Inclusivism in the Texts from Qumran and the Absence of a Reception History for Gen 12:3, w: G o o d m a n M. i in. (red.), Abraham, the Nations, and the Hagarites: Jewish, Christian, and Islamic Perspectives on Kinship with Abraham, Themes in Biblical Narrative 13, Leiden-Boston 2010, s. 77-103.

$\mathrm{Pu}$ e ch E., Fragments du Psaume 122 dans un manuscrit hébreu de la grotte IV, RQ 9/1978, s. 547-554.

$\mathrm{P}$ u e c h E., La Pierre de Sion et l'autel des holocaustes d'apres un manuscrit hébreu de la grotte 4 (4Q522), RB 99/1992, s. 676-696.

Q i m r o n E., Concerning "Joshua Cycles" from Qumran, Tarbiz 63/1994, s. 503-508 (w języku hebrajskim, angielskie podsumowanie).

R ofe A., "No Ephod or Teraphim" - oude hierateias oude delon: Hosea 3,4 in the LXX and in the Paraphrase of Chronicles and the Damascus Document, w: C o h e n C. i in. (red.), Sefer Moshe: The Moshe Weinfeld Jubilee Volume. Studies in the Bible and the Ancient Near East, Qumran, and Post-Biblical Judaism, Winona Lake 2004, s. 135-149. 
$\mathrm{S} \mathrm{c} \mathrm{h}$ if $\mathrm{f} \mathrm{m}$ a $\mathrm{n}$ L.H., The Construction of the Temple According to the Temple Scroll, RQ 17/1996, s. 555-571.

S c h n i e d e w in d W.M., A Qumran Fragment of the Ancient "Prayer of Manasseh"? ZAW 108/1996, s. 105-107.

S chulle r E.M., 4Q380 and 4Q381: Non-Canonical Psalms from Qumran, w: D i m a n t D., R a p pa p or t U. (red.), The Dead Sea Scrolls: Forty Years of Research, STDJ 10, Leiden 1992, s. 90-99.

S c hulle r E.M., Non-Canonical Psalms from Qumran: A Pseudepigraphic Collection, HSS 28, Atlanta 1986.

S e g a 1 M., The Book of Jubilees: Rewritten Bible, Redaction, Ideology, and Theology, JSJSup 117, Leiden-Boston 2007.

S t e in s G., Die Chronik als kanonisches Abschlussphänomen: Studien zur Entstehung und Theologie von 1/2 Chronik, BBB 93, Bodenheim 1995.

$\mathrm{S} w$ a $\mathrm{n}$ s o $\mathrm{n}$ D.D., The Temple Scroll and the Bible: The Methodology of 11QT, STDJ 14, Leiden 1995.

$\mathrm{S} w$ a $\mathrm{n}$ s o $\mathrm{n}$ D.D., The Use of Chronicles in 11QT: Aspects of a Relationship, w: D i m a n t D., R a p p a p or t U. (red.), The Dead Sea Scrolls: Forty Years of Research, STDJ 10, Leiden 1992, s. 290-298.

To v E., Joshua, Book of, w: S c h if f m a n L., V a n d e r K a m J.C. (red.), Encyclopedia of the Dead Sea Scrolls, t. I, New York 2000, s. 431-434.

Tov E., The Rewritten Book of Joshua as Found at Qumran and Masada, w: t e n ż e, Hebrew Bible, Greek Bible, and Qumran: Collected Essays, TSAJ 121, Tübingen 2008, s. 71-91.

Tre bolle B a r re r a J., Chronicles, First and Second Books of, w: S c h if f$\mathrm{m}$ a $\mathrm{n}$ L., V a n d e r K a m J.C. (red.), Encyclopedia of the Dead Sea Scrolls, t. I, New York 2000, s. 129.

Tr o $\mathrm{n}$ in a A., Biblia w Qumran. Wprowadzenie w lekturę biblijnych rękopisów znad Morza Martwego, BZ.TNT 8, Kraków 2001.

Tr o $\mathrm{n}$ in a A., Pierwsza Księga Kronik. Wstęp, przekład z oryginatu, komentarz, NKB.ST 10/1, Częstochowa 2015.

V a n d e r K a m J.C., F 1 in t P.W., The Meaning of the Dead Sea Scrolls: Their Significance for Understanding the Bible, Judaism, Jesus, and Christianity, San Francisco 2002.

Y a d in Y., The Temple Scroll, t. I: Introduction, Jerusalem 1983.

$\mathrm{Z}$ a h $\mathrm{n}$ M.M., The Levites, the Royal Council, and the Relationship between Chronicles and the Temple Scroll, w: J o k i r a n t a J., Z a h n M.M. (red.), Law, Literature, and Society in Legal Texts from Qumran. Papers from the Ninth Meeting of the International Organisation for Qumran Studies, Leuven 2016, STDJ 128, Leiden 2019, s. 253-269. 